\title{
A Review of Patterns of Multiple Paternity Across Sea Turtle Rookeries
}

\author{
Patricia L.M. Lee*, Gail Schofield*, Rebecca I. Haughey*, \\ Antonios D. Mazaris ${ }^{\dagger}$, Graeme C. Hays ${ }^{*, 1}$ \\ ${ }^{*}$ Centre for Integrative Ecology, Deakin University, Geelong, VIC, Australia \\ ${ }^{\dagger}$ School of Biology, Aristotle University of Thessaloniki, Thessaloniki, Greece \\ ${ }^{1}$ Corresponding author: e-mail address: g.hays@ deakin.edu.au
}

\section{Contents}

1. Background 2

2. Sea Turtles as a Model Group for Exploring Patterns of Multiple Paternity 3

3. The Incidence of Multiple Paternity vs Species and Rookery Size 5

4. Case Studies: The Extent of Individual Movements Across Rookeries 16

5. Packing Density and Incidence of Multiple Paternity 17

6. Movement Appears Critical to Estimating Density and Mate Encounter Rate 19

7. Conclusion 22

Acknowledgement $\quad 23$

Authors' Contributions $\quad 23$

Competing Interests 23

Funding $\quad 23$

References $\quad 24$

\begin{abstract}
Why females would mate with multiple partners and have multiple fathers for clutches or litters is a long-standing enigma. There is a broad dichotomy in hypotheses ranging from polyandry having benefits to simply being an unavoidable consequence of a high incidence of male-female encounters. If females simply give in to mating when it is too costly to avoid being harassed by males (convenience polyandry), then there should be a higher rate of mating as density increases. However, if females actively seek males because they benefit from multiple mating, then mating frequency, and consequently the incidence of multiple paternity of clutches, should be high throughout. To explore these competing explanations, here we review the incidence of multiple paternity for sea turtles nesting around the World. Across 30 rookeries, including all 7 species of sea turtle, the incidence of multiple paternity was only weakly linked to rookery size $\left(r^{2}=0.14\right)$. However, using high resolution at-sea GPS tracking we show that the specifics of movement patterns play a key role in driving packing density and hence the
\end{abstract}


likely rate of male-female encounters. When individuals use the same focal areas, packing density could be $100 \times$ greater than when assuming individuals move independently. Once the extent of adult movements in the breeding season was considered so that movements and abundance could be combined to produce a measure of density, then across rookeries we found a very tight relationship $\left(r^{2}=0.96\right)$ between packing density and the incidence of multiple paternity. These findings suggest that multiple paternity in sea turtles may have no benefit, but is simply a consequence of the incidence of male-female encounters.

\section{BACKGROUND}

While the evolution of male promiscuity holds no mysteries, why females would mate with more than one male to fertilise a clutch of eggs remains an outstanding question despite over a decade of empirical and theoretical study and review (for example, Byrne and Roberts, 2012; Jennions and Petrie, 2000; Pearse and Avise, 2001; Simmons, 2005; Slatyer et al., 2012b; Taylor et al., 2014; Tregenza and Wedell, 2000; Uller and Olsson, 2008). There are many hypotheses for female multiple mating (polyandry), but it remains equivocal if there are female benefits of multiple mating or if multiple mating is simply a consequence of high male-female encounters. Additionally, male behaviour may influence the mating patterns of females by preventing access to females by other males (Connor et al., 2001; Olsson et al., 2005) or by aggressive harassment of females (Griffiths et al., 2012). Whether females benefit from promiscuous behaviour has been frequently reviewed and empirically tested, both experimentally and in natural populations, and in a wide variety of animal models. The suggested benefits include fertilisation assurance (Caspers et al., 2014; Uller and Olsson, 2005), genetic benefits (Jennions and Petrie, 2000; Olsson et al., 2011; Slatyer et al., 2012b; Zeh and Zeh, 2001), inbreeding avoidance (While et al., 2014), postcopulatory sexual selection (Adams et al., 2005; Caspers et al., 2014; Zeh and Zeh, 2008), "hedge-betting" against infertility, genetic incompatibility or variable environments (Garcia-Gonzalez et al., 2015; Yasui and Garcia-Gonzalez, 2016) and obtaining protection or resources from additional males (Arnqvist and Nilsson, 2000; Reichard et al., 2007; Slatyer et al., 2012a). In contrast, while the mate-encounter-rate hypothesis has been explored with theory (Kokko and Mappes, 2013), suggested as a logistical limit on polygamous mating (Avise and Liu, 2011), and invoked in cases for which there are no obvious benefits for 
females (for example, Byrne and Roberts, 2004; Griffiths et al., 2012; Uller and Olsson, 2008; Zhao et al., 2016), it has been little explored in natural populations.

\section{SEA TURTLES AS A MODEL GROUP FOR EXPLORING PATTERNS OF MULTIPLE PATERNITY}

To explore the mate-encounter-rate hypothesis in natural populations, sea turtles are a useful model group since there can be massive differences in rookery (breeding population) sizes (a few 10s to $>100,000$ nesting females) and, to date, there has been no evidence that females benefit from having multiple mates. For sea turtles, there are no direct benefits for having multiple mates because there is no parental care and no social bonds between the sexes (Fig. 1). No evidence for genetic (indirect) benefits has so far been detected (Alfaro-Núnez et al., 2015; Lee and Hays, 2004; Wright et al., 2013) with fitness indicators such as clutch size, hatching success or offspring quality being typically compared between single-fathered clutches and those with multiple fathers. However, it has also been argued that indirect benefits may only be easily detected in genetically impoverished and inbred populations (Madsen, 2008).

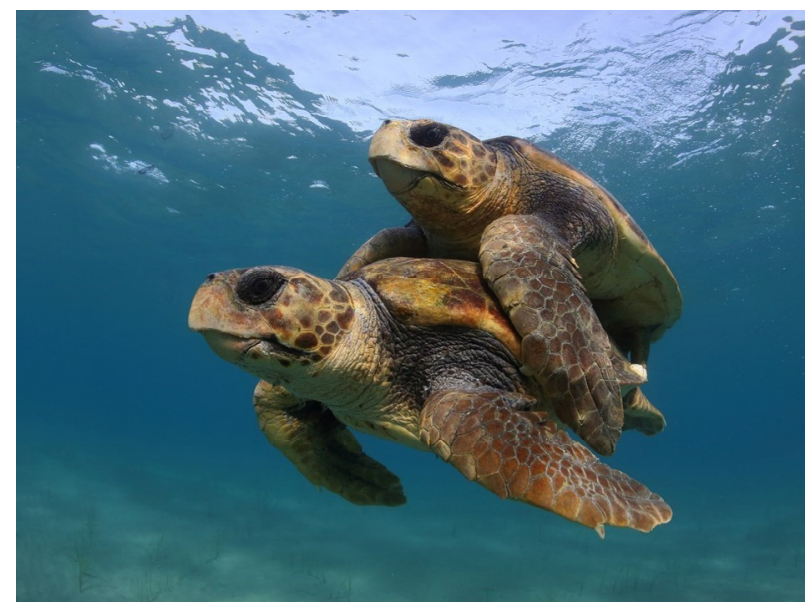

Fig. 1 In sea turtles, males and females congregate to mate close to nesting beaches. They can both mate with multiple partners. After the breeding season males travel to sometimes distant foraging grounds, while females lay multiple clutches of eggs ashore using stored sperm to fertilise clutches. (Photo courtesy of Kostas Papafitsoros). 
There is an alternative approach to the problem. If females do indeed benefit from multiple mating, then it would be expected that females will actively search for males and so there ought to then be high incidences of multiple paternity across rookeries, so long as density was not a limiting factor. In contrast, if the incidence of multiple paternity was simply a consequence of male-female packing density, we would then expect the incidence of multiple paternity in a rookery to scale with the density of breeding males and females. Indeed Jensen et al. (2006) had shown a correlation between the incidence of multiple paternity and the size of the rookery as indicated by the number of nests or nesting females. However, subsequently some rookeries have been found not to fit with this relationship (Lasala et al., 2013; Zbinden et al., 2007). We might expect that abundance will only loosely predict male-female encounters, since rookeries with low abundance might occupy very small areas and vice versa and so abundance alone is probably a poor proxy for adult density on the breeding grounds (Lee, 2008).

A further factor to consider is sex ratio. The density of animals on the breeding grounds will obviously influence the likelihood of individuals meeting. However, if the operational sex ratio is skewed, the actual mate-encounter-rate will be lower (Kokko and Rankin, 2006). Operational sex ratios are difficult to assess for sea turtles, but it is possible to estimate the hatchling sex ratio through analyses of nest temperatures (Mrosovsky, 1994), and these analyses have indicated the hatchling sex ratio of many rookeries are female skewed. However, the operational sex ratio is likely to be more balanced than indicated by hatchling sex ratios since males return to breeding areas more frequently than females (Hays et al., 2010, 2014). If the operational sex ratio is indeed relatively balanced at most rookeries, then this value cannot explain the variability in the incidence of multiple paternity. Instead, an improved indicator of adult density on the breeding grounds may be what is required.

As an extension to the mate-encounter-rate theory, we suggest that movement, which has not been previously considered, may be a further component in determining animal density on the breeding grounds. Here, we investigate two factors that are likely to influence mate encounter rate, and hence, female promiscuity: abundance (rookery size) and movement. First, we conduct the most extensive review to date for how rookery size is linked to female promiscuity among sea turtles. Second but most crucially, we hypothesise that the area occupied by individuals in the breeding season combined with rookery size may provide a far more realistic estimate of 
packing density on the breeding grounds and hence, the incidence of multiple paternity. We test this hypothesis using published tracking data to assess the extent of individual movements in the breeding season. Finally, we objectively develop an index of packing density in the breeding season to compare against the incidence of multiple paternity.

\section{THE INCIDENCE OF MULTIPLE PATERNITY VS SPECIES AND ROOKERY SIZE}

We begin with a review of studies estimating the incidence of multiple paternity in sea turtle rookeries (breeding sites). Two independent literature searches were conducted (P.L.M.L. with R.I.H. and A.D.M.) using the search engines Web-of-Knowledge (WOK; http://apps.webofknowledge. com/), SCOPUS (http://www.scopus.com/) and Google Scholar (http:// scholar.google.com/). Typical keywords used in searches were "polyandry", "multiple paternity", "parentage" and "turtle". We considered conference reports, book chapters and student theses in addition to journal publications, but limited records to studies using molecular markers to estimate the incidence of multiple paternity. Initial searches were started in December 2014, and records continued to be monitored by setting up citation alerts. The references of records were also examined for further reports. The data search was terminated in February 2016.

We considered clutches from the same female in the same breeding season as a single sample. For studies that only reported the incidence of multiple paternity per clutch, we assumed each clutch had been laid by a different female. Studies with sample sizes less than five were excluded, as these were likely to provide the poorest estimates of the incidence of multiple paternity in a rookery. For rookeries with the incidence of multiple paternity estimated in different years, we reduced the data to a single estimate to avoid pseudoreplication. How this was achieved was decided on a caseby-case basis. Older studies were often constrained by low sample size, or used less informative molecular markers (e.g. DNA fingerprints); these were excluded in favour of the more recent study. Alternatively, if the estimates were conducted close in time, sample sizes were similar, and the rookery size did not vary by more than a magnitude, we combined the data as a single estimate.

The two independent literature searches overlapped by $76 \%$, and together yielded reports of the incidence of multiple paternity for 40 sea turtle rookeries (Tables 1 and 2). While there will be studies that were not 
Table 1 Incidences of Multiple Paternity (\%), Rookery Sizes (Nest Count and the Number of Nesting Females), an Index of Offshore Movement (km) and Their Associated References

\begin{tabular}{|c|c|c|c|c|c|c|c|c|c|c|c|c|}
\hline Location & Species & $\begin{array}{l}\text { Incidence } \\
\text { of Multiple } \\
\text { Paternity } \\
\text { (\%) }\end{array}$ & $\begin{array}{l}\text { Sample Size } \\
\text { (N) }\end{array}$ & $\begin{array}{l}\text { Year of } \\
\text { Study }\end{array}$ & References & $\begin{array}{l}\text { Nest } \\
\text { Count (N) }\end{array}$ & $\begin{array}{l}\text { Number of } \\
\text { Nesting } \\
\text { Females (N) }\end{array}$ & $\begin{array}{l}\text { Variable } \\
\text { Counted }\end{array}$ & $\begin{array}{l}\text { Year of } \\
\text { Abundance } \\
\text { Estimate }\end{array}$ & References & $\begin{array}{l}\text { Offshore } \\
\text { Distance } \\
(\mathrm{km})\end{array}$ & References \\
\hline $\begin{array}{l}\text { Mon Repos, } \\
\text { near } \\
\text { Bundaberg, } \\
\text { Queensland } \\
\text { (Australia) }\end{array}$ & Flatback & 67 & 6 & $2004 / 5$ & $\begin{array}{l}\text { Theissinger } \\
\text { et al. (2009) }\end{array}$ & 90 & 30 & Females & 2004 & $\begin{array}{l}\text { Limpus et al. } \\
(2013)\end{array}$ & NA & NA \\
\hline $\begin{array}{l}\text { Heron Island, } \\
\text { Southern Great } \\
\text { Barrier Reef } \\
\text { (Australia) }\end{array}$ & Green & 15 & 13 & $1991 / 2,1993 / 4$ & $\begin{array}{l}\text { Fitzsimmons } \\
(1998)\end{array}$ & 1641 & 547 & Females & $\begin{array}{l}1991 / 2 \\
1993 / 4\end{array}$ & $\begin{array}{l}\text { Department of } \\
\text { Environment } \\
\text { and Heritage } \\
\text { Protection } \\
\text { (2013) }\end{array}$ & NA & NA \\
\hline $\begin{array}{l}\text { Ascension } \\
\text { Island, South } \\
\text { Atlantic } \\
\text { (British } \\
\text { Overseas } \\
\text { Territory) }\end{array}$ & Green & 61 & 18 & 1999,2000 & $\begin{array}{l}\text { Ireland et al. } \\
(2003), \text { Lee } \\
\text { and Hays } \\
(2004)\end{array}$ & 11,836 & 3945 & Nests & 1999, 2000 & $\begin{array}{l}\text { Weber et al. } \\
(2014)\end{array}$ & $2.5^{c}$ & $\begin{array}{l}\text { Hays et al. } \\
(1999)\end{array}$ \\
\hline $\begin{array}{l}\text { Tortuguero } \\
\text { (Caribbean } \\
\text { coast of Costa } \\
\text { Rica) }\end{array}$ & Green & 92 & 12 & 2007 & $\begin{array}{l}\text { Alfaro-Núñez } \\
\text { et al. (2015) }\end{array}$ & 177,290 & 59,097 & Nests & 2007 & $\begin{array}{l}\text { Prieto and } \\
\text { Harrison (2012) }\end{array}$ & NA & NA \\
\hline $\begin{array}{l}\text { Alagadi Beach } \\
\text { (northern } \\
\text { Cyprus) }\end{array}$ & Green & 24 & 78 & $2008,2009,2010$ & $\begin{array}{l}\text { Wright et al. } \\
(2013)\end{array}$ & 88 & 30 & Both & $\begin{array}{l}2008, \\
2009,2010\end{array}$ & $\begin{array}{l}\text { Stokes et al. } \\
(2014)\end{array}$ & NA & NA \\
\hline $\begin{array}{l}\text { Kosgoda } \\
\text { (Sri Lanka) }\end{array}$ & Green & 47 & 19 & $2005 / 6$ & $\begin{array}{l}\text { Ekanayake } \\
\text { et al. (2013) }\end{array}$ & 400 & 133 & Nests & $2005 / 6$ & $\begin{array}{l}\text { Ekanayake et al. } \\
(2010)\end{array}$ & NA & NA \\
\hline $\begin{array}{l}\text { Melbourne } \\
\text { Beach, south } \\
\text { Florida (USA) }\end{array}$ & Green & 86 & 28 & 2011, 2012 & Long (2013) & 4721 & 1574 & Nests & 2011, 2012 & $\begin{array}{l}\text { US Fish and } \\
\text { Wildlife Service } \\
(2015)\end{array}$ & NA & NA \\
\hline
\end{tabular}




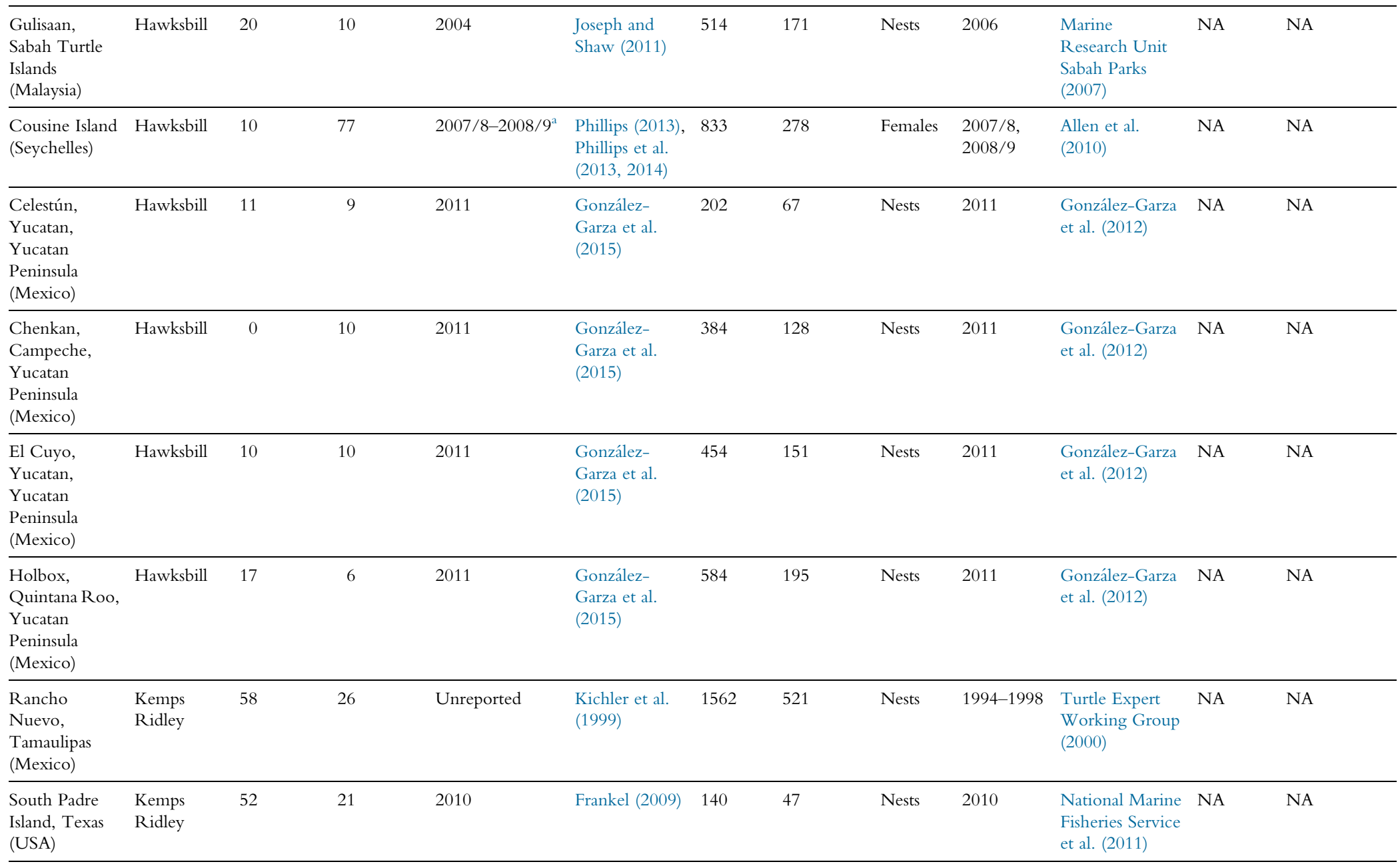


Table 1 Incidences of Multiple Paternity (\%), Rookery Sizes (Nest Count and the Number of Nesting Females), an Index of Offshore Movement (km) and Their Associated References-cont'd

\begin{tabular}{|c|c|c|c|c|c|c|c|c|c|c|c|c|}
\hline Location & Species & $\begin{array}{l}\text { Incidence } \\
\text { of Multiple } \\
\text { Paternity } \\
(\%)\end{array}$ & $\begin{array}{l}\text { Sample Size } \\
\text { (N) }\end{array}$ & $\begin{array}{l}\text { Year of } \\
\text { Study }\end{array}$ & References & $\begin{array}{l}\text { Nest } \\
\text { Count (N) }\end{array}$ & $\begin{array}{l}\text { Number of } \\
\text { Nesting } \\
\text { Females (N) }\end{array}$ & $\begin{array}{l}\text { Variable } \\
\text { Counted }\end{array}$ & $\begin{array}{l}\text { Year of } \\
\text { Abundance } \\
\text { Estimate }\end{array}$ & References & $\begin{array}{l}\text { Offshore } \\
\text { Distance } \\
(\mathrm{km})\end{array}$ & References \\
\hline $\begin{array}{l}\text { Playa Gandoca, } \\
\text { Gandoca- } \\
\text { Manzanillo } \\
\text { National } \\
\text { Wildlife } \\
\text { Refuge } \\
\text { (Caribbean } \\
\text { coast of Costa } \\
\text { Rica) }\end{array}$ & Leatherback & 22 & 18 & 2008 & $\begin{array}{l}\text { Figgener et al. } \\
(2016)\end{array}$ & 3044 & 1015 & Nests & 2008 & $\begin{array}{l}\text { Debade et al. } \\
(2009) \text {, Rivas } \\
\text { et al. (2015), } \\
\text { Troëng et al. } \\
\text { (2004), and } \\
\text { Widecast } \\
(2008)^{\mathrm{b}}\end{array}$ & $20.3^{\mathrm{d}}$ & NA \\
\hline $\begin{array}{l}\text { Playa Grande, } \\
\text { Parque Marino } \\
\text { Nacional Las } \\
\text { Baulas (Pacific } \\
\text { coast of Costa } \\
\text { Rica) }\end{array}$ & Leatherback & 10 & 20 & 1998/99 & $\begin{array}{l}\text { Crim et al. } \\
(2002)\end{array}$ & 378 & 126 & Females & 1998/99 & $\begin{array}{l}\text { Tomillo et al. } \\
(2007)\end{array}$ & $12^{\mathrm{e}}$ & $\begin{array}{l}\text { Shillinger et al. } \\
(2010)\end{array}$ \\
\hline $\begin{array}{l}\text { Matura Beach } \\
\text { (Trinidad) }\end{array}$ & Leatherback & 20 & 10 & 2009 & Nugent (2012) & 5642 & 3757 & Both & 2009 & Bachan (2009) & $19^{\mathrm{f}}$ & Eckert (2006) \\
\hline $\begin{array}{l}\text { Sandy Point } \\
\text { National } \\
\text { Wildlife } \\
\text { Refuge, } \\
\text { St. Croix } \\
\text { (US Virgin } \\
\text { Islands) }\end{array}$ & Leatherback & 27 & 67 & 2009,2010 & $\begin{array}{l}\text { Stewart and } \\
\text { Dutton (2011, } \\
\text { 2014) }\end{array}$ & 444 & 148 & Females & 2009,2010 & Garner (2012) & $30^{\mathrm{g}}$ & Eckert (2002) \\
\hline $\begin{array}{l}\text { Turtle Bay, } \\
\text { Dirk Hartog } \\
\text { Island, } \\
\text { Western } \\
\text { Australia } \\
\text { (Australia) }\end{array}$ & Loggerhead & 36 & 14 & 2013 & $\begin{array}{l}\text { Tedeschi et al. } \\
\text { (2015) }\end{array}$ & 4500 & 1500 & Females & $\begin{array}{l}1993 / 4- \\
1999 / 2000\end{array}$ & $\begin{array}{l}\text { Baldwin et al. } \\
(2003)\end{array}$ & NA & NA \\
\hline
\end{tabular}




\begin{tabular}{|c|c|c|c|c|c|c|c|c|c|c|c|c|}
\hline $\begin{array}{l}\text { Gnaraloo Bay, } \\
\text { Western } \\
\text { Australia } \\
\text { (Australia) }\end{array}$ & Loggerhead & 86 & 7 & 2011 & $\begin{array}{l}\text { Tedeschi et al. } \\
(2015)\end{array}$ & 397 & 132 & Nests & 2011 & $\begin{array}{l}\text { Hattingh et al. } \\
\text { (2014) }\end{array}$ & NA & NA \\
\hline $\begin{array}{l}\text { Mon Repos, } \\
\text { near } \\
\text { Bundaberg, } \\
\text { Queensland } \\
\text { (Australia) }\end{array}$ & Loggerhead & 33 & 24 & $1982 / 3$ & $\begin{array}{l}\text { Harry and } \\
\text { Briscoe (1988) }\end{array}$ & 945 & 315 & Females & $1982 / 3$ & Limpus (2009) & $3.5^{\mathrm{h}}$ & $\begin{array}{l}\text { Tucker et al. } \\
(1996)\end{array}$ \\
\hline $\begin{array}{l}\text { Zakynthos } \\
\text { Island (Greece) }\end{array}$ & Loggerhead & 93 & 15 & 2003,2004 & $\begin{array}{l}\text { Zbinden et al. } \\
(2007)\end{array}$ & 1198 & 399 & Nests & 2003,2004 & $\begin{array}{l}\text { Margaritoulis } \\
\text { et al. (2011) }\end{array}$ & $1^{\mathrm{i}}$ & $\begin{array}{l}\text { Schofield et al. } \\
\text { (2013) }\end{array}$ \\
\hline $\begin{array}{l}\text { Melbourne } \\
\text { Beach, south } \\
\text { Florida (USA) }\end{array}$ & Loggerhead & 31 & 70 & 1996 & $\begin{array}{l}\text { Moore and } \\
\text { Ball (2002) }\end{array}$ & 20,024 & 6675 & Nests & 1996 & $\begin{array}{l}\text { Scarborough } \\
(2013)\end{array}$ & $6.1^{j}$ & $\begin{array}{l}\text { Arendt et al. } \\
(2012)\end{array}$ \\
\hline $\begin{array}{l}\text { Wassaw } \\
\text { National } \\
\text { Wildlife } \\
\text { Refuge, } \\
\text { Wassaw Island, } \\
\text { Georgia (USA) }\end{array}$ & Loggerhead & 75 & 72 & 2008-2010 & $\begin{array}{l}\text { Lasala et al. } \\
(2013)\end{array}$ & 123 & 57 & Both & $2008-2010$ & $\begin{array}{l}\text { Pfaller et al. } \\
(2013)\end{array}$ & NA & NA \\
\hline $\begin{array}{l}\text { Quintana Roo, } \\
\text { Yucatan } \\
\text { Peninsula } \\
\text { (Mexico) }\end{array}$ & Loggerhead & 66 & 41 & 2006 & Nielsen (2010) & 1225 & 408 & Nests & 2006 & $\begin{array}{l}\text { Comision } \\
\text { Nacional De } \\
\text { Areas Naturales } \\
\text { Protegidas } \\
(2011)\end{array}$ & NA & NA \\
\hline $\begin{array}{l}\text { St. George } \\
\text { Island, } \\
\text { northwestern } \\
\text { Florida (USA) }\end{array}$ & Loggerhead & 23 & 22 & 2007,2008 & Nielsen (2010) & 141 & 47 & Nests & 2007 & $\begin{array}{l}\text { Florida } \\
\text { Department of } \\
\text { Environmental } \\
\text { Protection } \\
(2015)\end{array}$ & NA & NA \\
\hline
\end{tabular}


Table 1 Incidences of Multiple Paternity (\%), Rookery Sizes (Nest Count and the Number of Nesting Females), an Index of Offshore Movement (km) and Their Associated References-cont'd

Incidence
of Multiple

\begin{tabular}{|c|c|c|c|c|c|c|c|c|c|c|c|c|}
\hline Location & Species & $\begin{array}{l}\text { of Multiple } \\
\text { Paternity } \\
\text { (\%) }\end{array}$ & $\begin{array}{l}\text { Sample Size } \\
\text { (N) }\end{array}$ & $\begin{array}{l}\text { Year of } \\
\text { Study }\end{array}$ & References & $\begin{array}{l}\text { Nest } \\
\text { Count (N) }\end{array}$ & $\begin{array}{l}\text { Number of } \\
\text { Nesting } \\
\text { Females (N) }\end{array}$ & $\begin{array}{l}\text { Variable } \\
\text { Counted }\end{array}$ & $\begin{array}{l}\text { Year of } \\
\text { Abundance } \\
\text { Estimate }\end{array}$ & References & $\begin{array}{l}\text { Offshore } \\
\text { Distance } \\
(\mathrm{km})\end{array}$ & References \\
\hline $\begin{array}{l}\text { Ostional } \\
\text { National }\end{array}$ & Olive ridley & 92 & 13 & 2003 & $\begin{array}{l}\text { Jensen et al. } \\
(2006)\end{array}$ & 375,000 & 125,000 & Females & 2003 & $\begin{array}{l}\text { Conant et al. } \\
\text { (2014) }\end{array}$ & NA & NA \\
\hline
\end{tabular}

National

Wildlife

Refuge

(Pacific coast of

Costa Rica)

\begin{tabular}{|c|c|c|c|c|c|c|c|c|c|c|c|c|}
\hline $\begin{array}{l}\text { Playa Hermosa } \\
\text { National } \\
\text { Wildlife } \\
\text { Refuge } \\
\text { (Pacific coast of } \\
\text { Costa Rica) }\end{array}$ & Olive ridley & 31 & 13 & 2003 & $\begin{array}{l}\text { Jensen et al. } \\
(2006)\end{array}$ & 1185 & 395 & Nests & 2008 & $\begin{array}{l}\text { Mast et al. } \\
(2014-2015)\end{array}$ & NA & NA \\
\hline $\begin{array}{l}\text { Galibi Nature } \\
\text { Reserve (East } \\
\text { Suriname) }\end{array}$ & Olive ridley & 20 & 10 & 1995 & $\begin{array}{l}\text { Hoekert et al. } \\
(2002)\end{array}$ & 335 & 112 & Nests & 1995 & $\begin{array}{l}\text { Hoekert et al. } \\
(2002)\end{array}$ & NA & NA \\
\hline $\begin{array}{l}\text { Punta Raton } \\
\text { (Honduras) }\end{array}$ & Olive ridley & 75 & 8 & 2011-2013 & $\begin{array}{l}\text { Duran et al. } \\
(2015)\end{array}$ & NA & NA & NA & NA & NA & NA & NA \\
\hline
\end{tabular}

${ }^{2}$ These studies were undertaken over 2007/8-2010/11 with a total sample size of 140 (incidence of multiple paternity, 9\%) but data for only 2 years were used for analyses since rookery data for the other years were not available.

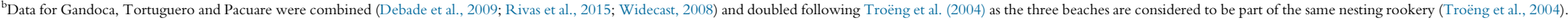
"Based both on the mean distances moved offshore of tracked individuals as well as diving data indicating individuals typically rested at depths of $<20 \mathrm{~m}$, a bathymetric contour readily seen on nautical charts.

${ }^{\mathrm{d}}$ Based on the mean value recorded for other leatherback tracking studies reported in this Table (see footnotes $\mathrm{e}, \mathrm{f}, \mathrm{g}$ ).

${ }^{\mathrm{e}}$ Based on the reported $50 \%$ Kernel Utilisation Density of tracked individuals.

Based on the reported $50 \%$ Kernel Utilisation Density of tracked individual.

"Based on the reported radio telemetry locations, of which $38 \%$ of locations were concentrated within the "turtle protection special management area".

${ }^{\mathrm{B}}$ Based on the reported $50 \%$ Kernel Utilisation Density of tracked individuals.

${ }^{\mathrm{j}} \mathrm{Based}$ on the reported minimum convex polygon core area use of tracked individuals during the breeding period.

NA indicates missing data. 
Table 2 Details of Studies Reporting Multiple Paternity in Sea Turtles That Were Excluded From Analyses

\begin{tabular}{|c|c|c|c|c|c|c|}
\hline Location & Species & $\begin{array}{l}\text { Incidence of } \\
\text { Multiple } \\
\text { Paternity (\%) }\end{array}$ & $\begin{array}{l}\text { Sample } \\
\text { Size (N) }\end{array}$ & $\begin{array}{l}\text { Year of } \\
\text { Study }\end{array}$ & References & Reason for Exclusion \\
\hline $\begin{array}{l}\text { Peak Island, Queensland } \\
\text { (Australia) }\end{array}$ & Flatback & 67 & 3 & $2004 / 5$ & $\begin{array}{l}\text { Theissinger et al. } \\
(2009)\end{array}$ & Small sample size $<5$ \\
\hline $\begin{array}{l}\text { Tortuguero (Caribbean } \\
\text { coast of Costa Rica) }\end{array}$ & Green & 63 & 8 & Unreported & Peare et al. (1998) & $\begin{array}{l}\text { Replaced by a more recent study by } \\
\text { Alfaro-Núñez et al. (2015) }\end{array}$ \\
\hline Pangumbahan (Java) & Green & 50 & 10 & Unreported & $\begin{array}{l}\text { Purnama et al. } \\
\text { (2013) }\end{array}$ & $\begin{array}{l}\text { Interannual variability of nest } \\
\text { numbers was too great to accept an } \\
\text { average value from multiple years } \\
\text { given lack of information about the } \\
\text { year that MP samples was taken }\end{array}$ \\
\hline Khram Island (Thailand) & Green & 100 & 3 & 2001 & $\begin{array}{l}\text { Mudsuk et al. } \\
(2004)\end{array}$ & Small sample size $<5$ \\
\hline $\begin{array}{l}\text { Las Coloradas, Yucatan } \\
\text { Peninsula (Mexico) }\end{array}$ & Hawksbill & 0 & 4 & 2011 & $\begin{array}{l}\text { González-Garza } \\
\text { et al. (2015) }\end{array}$ & Small sample size $<5$ \\
\hline
\end{tabular}


Table 2 Details of Studies Reporting Multiple Paternity in Sea Turtles That Were Excluded From Analyses—cont'd

\begin{tabular}{|c|c|c|c|c|c|c|}
\hline Location & Species & $\begin{array}{l}\text { Incidence of } \\
\text { Multiple } \\
\text { Paternity (\%) }\end{array}$ & $\begin{array}{l}\text { Sample } \\
\text { Size (N) }\end{array}$ & $\begin{array}{l}\text { Year of } \\
\text { Study }\end{array}$ & References & Reason for Exclusion \\
\hline $\begin{array}{l}\text { Xicalango-Victoria, } \\
\text { Yucatan Peninsula } \\
\text { (Mexico) }\end{array}$ & Hawksbill & 0 & 2 & 2011 & $\begin{array}{l}\text { González-Garza } \\
\text { et al. (2015) }\end{array}$ & Small sample size $<5$ \\
\hline $\begin{array}{l}\text { Bungalup Beach, } \\
\text { Western Australia } \\
\text { (Australia) }\end{array}$ & Loggerhead & 25 & 4 & 2013 & $\begin{array}{l}\text { Tedeschi et al. } \\
(2015)\end{array}$ & Small sample size $<5$ \\
\hline $\begin{array}{l}\text { Melbourne Beach, } \\
\text { south Florida (USA) }\end{array}$ & Loggerhead & 33 & 3 & 1994 & $\begin{array}{l}\text { Bollmer et al. } \\
(1999)\end{array}$ & $\begin{array}{l}\text { Small sample size }<5 \text {; replaced by a } \\
\text { more recent study by Moore and Ball } \\
(2002)\end{array}$ \\
\hline $\begin{array}{l}\text { Pacuare (Caribbean } \\
\text { coast of Costa Rica) }\end{array}$ & Leatherback & 9 & 11 & 1996 & Curtis et al. (2000) & $\begin{array}{l}\text { Replaced by a more recent study by } \\
\text { Figgener et al. (2016) }\end{array}$ \\
\hline $\begin{array}{l}\text { Sandy Point National } \\
\text { Wildlife Refuge, } \\
\text { St. Croix (US Virgin } \\
\text { Islands) }\end{array}$ & Leatherback & 0 & 4 & Unreported & $\begin{array}{l}\text { Dutton et al. } \\
(2000)\end{array}$ & $\begin{array}{l}\text { Small sample size }<5 \text {; replaced by } \\
\text { more recent study by Stewart and } \\
\text { Dutton (2011) }\end{array}$ \\
\hline
\end{tabular}


Escobilla (Mexico) Olive ridley 50

16

Unreported Zurita et al. (2008)
This conference abstract did not include any detail on methodology, so it was not possible to assess the reliability of the study - in addition, there was conflicting data from a previous study (100\% MP of 4 nests), which also lacked information about methodology but neither the degree of multiple paternity in the rookery nor the sample size was reported 
found (e.g. student theses and unreported projects), this presents the most comprehensive set of sea turtle multiple paternity data to date, including all data up to February 2016 in ISI-listed journal publications for all seven species of sea turtle: green turtle Chelonia mydas (Linnaeus, 1758), loggerhead Caretta caretta (Linnaeus, 1758), Kemp's ridley Lepidochelys kempii (Garman, 1880), olive ridley Lepidochelys olivacea (Eschscholtz, 1829), hawksbill Eretmochelys imbricata (Linnaeus, 1766), flatback Natator depressus (Garman, 1880) and leatherback Dermochelys coriacea (Vandelli, 1761).

The incidence of multiple paternity varied hugely across rookeries (Fig. 2A and B), being found, for example, in $92.3 \%$ and $91.7 \%$ of clutches for olive ridley turtles nesting in Ostional (Costa Rica) and green turtles nesting in Tortuguero (Costa Rica), respectively; but only $10.0 \%$ and $20.0 \%$ of clutches for leatherback turtles nesting in Playa Grande (Costa Rica) and Matura (Trinidad), respectively. There were marked and significant (ANOVA, $F_{5,24}=3.7, P=0.013$ ) differences in the incidence of multiple paternity across species. For example, leatherback turtles had a significantly lower incidence of multiple paternity (mean 19.8\%, $n=4$ rookeries) than either loggerhead turtles (mean 55.4\%, $n=8$ rookeries, $T_{8}=3.42$, $P<0.01$ ) or green turtles (mean 54.3, $n=6$ rookeries, $T_{5}=2.60, P=0.04$ ). While the incidence of multiple paternity was uniformly low at leatherback turtle rookeries, it was more variable in other species. For example, for loggerhead turtles the incidence of multiple paternity in clutches ranged from 22.7\% (St. George Island, Florida) to 93.3\% (Zakynthos Island, Greece).

We then conducted literature searches for data on rookery sizes. Since rookery size may fluctuate from year to year, we attempted to collect rookery size data for the year when the incidence of multiple paternity had been estimated. For cases where this was not possible (e.g. the year of study was not reported), we examined the rookery size data for 5 years prior to the date of publication of the report and took an average value if the size did not vary by more than an order of magnitude during this period. Rookery size was usually reported as the number of nests counted in a breeding season, but sometimes the number of nesting females was reported. Where only one type of data was available, we converted between the data by assuming that female sea turtles laid an average of three clutches in a breeding season (Hirth, 1980). We applied an average value for consistency across the data because specific clutch frequency information was not available for all rookeries in our database.

Rookery size and the incidence of multiple paternity were obtained for 30 rookeries spanning the 7 species (Fig. 2 and Table 1). We found that the 
A

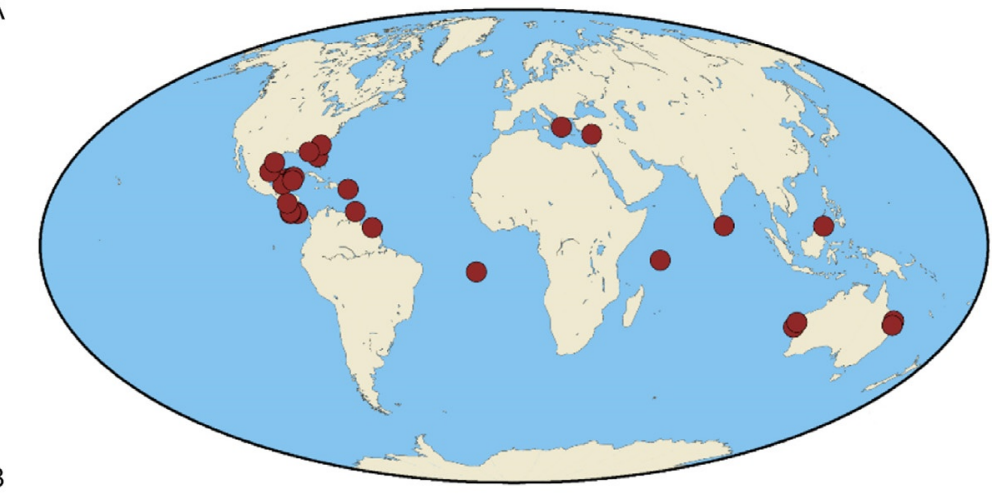

B
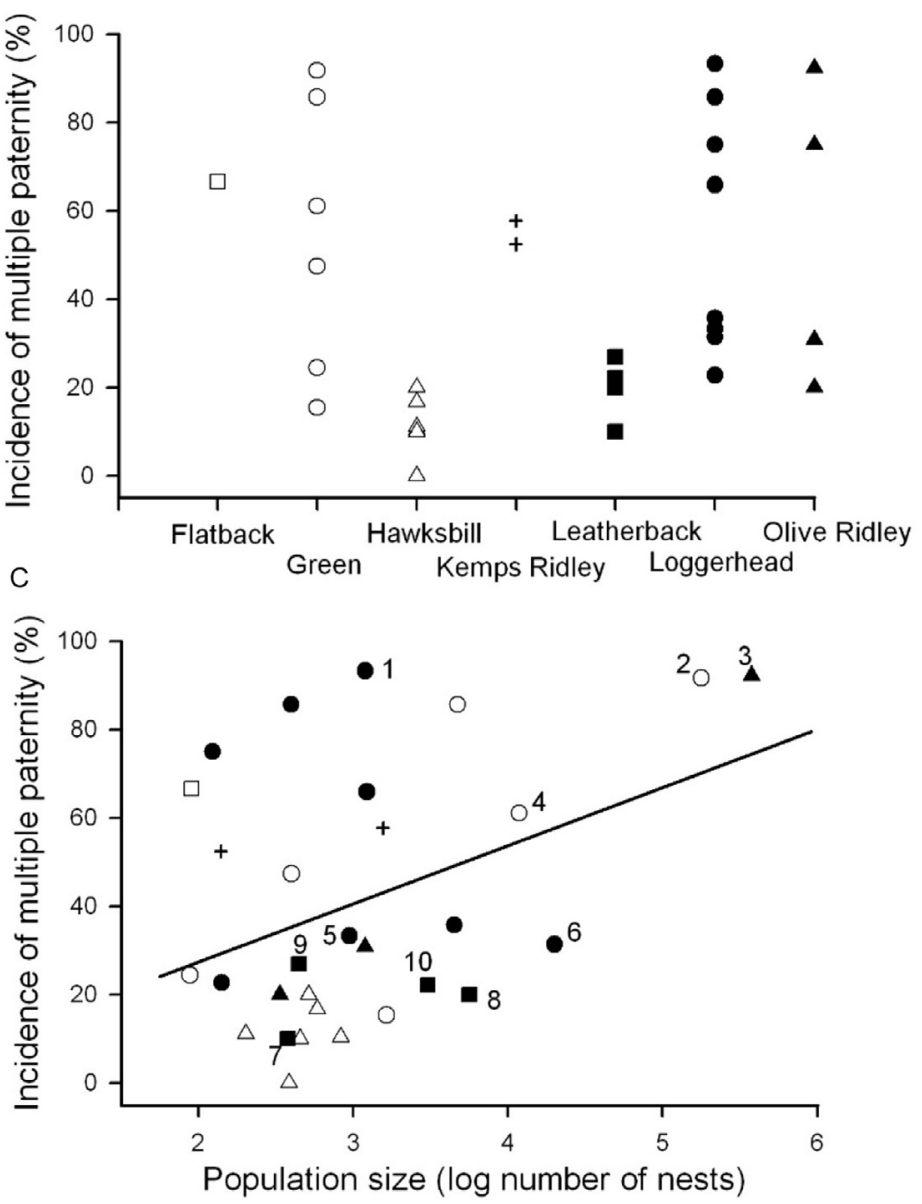

Fig. 2 The incidence of multiple paternity in sea turtle rookeries around the world. (A) Locations around the World where the incidence of multiple paternity has been 
incidence of multiple paternity was only weakly linked to rookery size $\left(F_{1,28}=5.25, R^{2}=0.158, P=0.03, n=30\right)$ (Fig. 2C). For example, while the incidence of multiple paternity was high at rookeries where nesting numbers were massive (e.g. 125,000 and 59,000 nests per year, respectively, at Ostional and Tortuguero), at smaller rookeries the incidences of multiple paternity were highly variable and poorly predicted by population size. For example, for loggerhead turtles at Chenkan (Mexico) where the rookery size was 945 nests, the incidence of multiple paternity was 33.3\%, while for loggerhead turtles at Zakynthos (Greece) which had a similar rookery size (1198 nests) the incidence was 93.3\% (Fig. 2C).

\section{CASE STUDIES: THE EXTENT OF INDIVIDUAL MOVEMENTS ACROSS ROOKERIES}

We suggest that the extent to which adults move within the breeding area could determine the packing density within rookeries. For breeding sites of two different species, loggerhead and leatherback turtles, we have previously tracked individuals in the breeding season. For loggerhead turtles at Zakynthos Island (Greece $37^{\circ} 43^{\prime} \mathrm{N} 20^{\circ} 53^{\prime} \mathrm{E}$ ), we used GPS loggers (Navsys Ltd. TrackTag TM GPS loggers; Colorado Springs, CO, USA; http://www.navsys.com) to track breeding females in 2006 (three females), 2007 (four females) and 2008 (six females). For details on permits, turtle capture, attachment and retrieval techniques see Schofield et al. (2007, 2013). Here, we filtered the GPS fixes (average of 51 fixes per turtle per day) by selecting the central location for each hour for each turtle (Tremblay et al., 2006). For leatherback turtles nesting in Grenada (Caribbean), we

Fig. 2-Cont'd measured, excluding rookeries where the samples size was $<5$ clutches. (B) Variation in the degree of multiple paternity across different species of sea turtle. Variation within species was particularly evident across rookeries of loggerhead turtles, olive ridley turtles and green turtles, whereas leatherbacks and hawksbills had uniformly low incidence of multiple paternity. (C) The relationship between the incidence of multiple paternity and the size of different rookeries as indicated by the number of nests. Plot symbols indicate different species as identified in (B). Selected sites are identified as they appear in Fig. 4. 1 =loggerhead turtles Zakynthos (Greece); $2=$ green turtles Tortuguero (Costa Rica); $3=$ olive ridley turtles Ostional (Costa Rica); $4=$ green turtles (Ascension Island); $5=$ loggerhead turtles Mon Repos (Australia); $6=$ loggerhead turtles, Melbourne Beach, Florida (USA); $7=$ leatherback turtles Playa Grande (Costa Rica); $8=$ leatherback turtles Matura (Trinidad); $9=$ leatherback turtles St. Croix (US Virgin Islands); $10=$ leatherback turtles Gandoca (Costa Rica). 
recorded the extent of their movements in the breeding season using Argos satellite tags (see Georges et al., 2007 for details of attachments and data processing).

We found that between breeding loggerhead turtles at Zakynthos (Greece) and leatherback turtles in Grenada (Caribbean) there were massive differences in the extent of individual movements. Loggerhead turtles at Zakynthos tended to have very restricted movements, generally staying within $1 \mathrm{~km}$ of their breeding beaches. By contrast, leatherback turtles breeding in Grenada travelled many 10s of $\mathrm{km}$ from their breeding beaches ranging over an area of around $25,000 \mathrm{~km}^{2}(250 \mathrm{~km}$ by $100 \mathrm{~km}$; Fig. 3). These contrasting movement behaviours from the two case studies justified the logic of incorporating movement data into estimates of density.

\section{PACKING DENSITY AND INCIDENCE OF MULTIPLE PATERNITY}

While tracking is often lacking during the breeding season, we used the available data to estimate the packing density across rookeries. We calculated a packing density metric as: $\log _{10}$ (number of nesting individuals)/ distance travelled offshore during the breeding season. To maximise the power of this analysis, we assembled the "distance travelled offshore" metric across rookeries in several ways. First where available, we used maps of the $50 \%$ Kernel Utilisation Density or maps that showed the core area used. Where kernel density maps were not available, we used the reported mean location of individuals during the breeding season or visually inspected the published tracks to estimate the typical distances travelled offshore. Where available data indicated a strong consistency across rookeries of the same species for the extent of their movements in the breeding season, we applied mean species values for movements offshore to rookeries where individuals have not been tracked. Finally, for rookeries where nesting numbers were exceptionally high (orders of magnitude higher than other rookeries) and so rookery size alone likely resulted in high packing densities, we assumed the maximal packing densities calculated from other sites with tracking data.

For rookeries across the World where we were able to estimate packing density, this density scaled very tightly with the incidence of multiple paternity $\left(F_{1,8}=241, R^{2}=0.97, P<0.001\right.$; Fig. 4$)$. The high degree of multiple paternity in the Zakynthos rookery corresponded with the high packing density of loggerhead turtles at this location, with this density driven by 


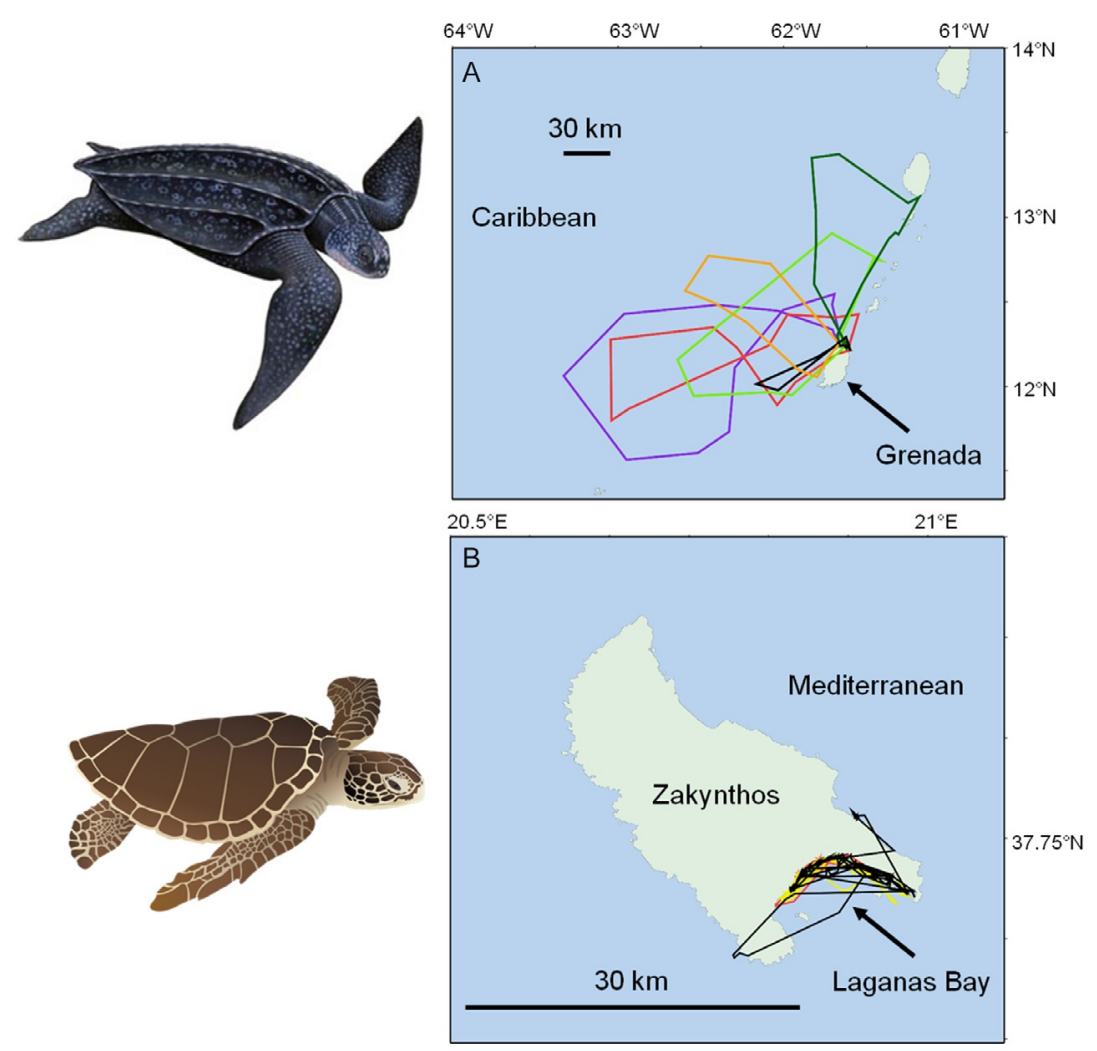

Fig. 3 The variable extent of movements during the breeding season across rookeries. (A) Leatherback turtles breeding in Grenada (Caribbean) and (B) loggerhead turtles breeding in Zakynthos (Greece). Panel (B) shows the tracks of three individuals tracked in 2006 with similar movements recorded in 2007 and 2008. Individuals made occasional excursions but $>90 \%$ of locations were within Laganas Bay (Zakynthos, Greece) and individuals spent the vast majority of their time very close to the nesting beaches. In contrast, leatherback turtles at Grenada (Panel A) travelled far more extensively in the breeding season, often more than $100 \mathrm{~km}$ from their nesting beaches. Tracks recorded during six separate internesting intervals are shown.

the very restricted movements of turtles at that site during the breeding season. We can also explain the high instances of multiple paternity at the massive rookeries (olive ridleys at Ostional and green turtles at Tortuguero), where the abundance of individuals will help ensure a high rate of malefemale encounters. In contrast, the leatherback turtles of St. Croix, Matura and Playa Grande demonstrate relatively low instances of multiple paternity, in line with their low packing density and hence individuals will be more diffusely distributed. 


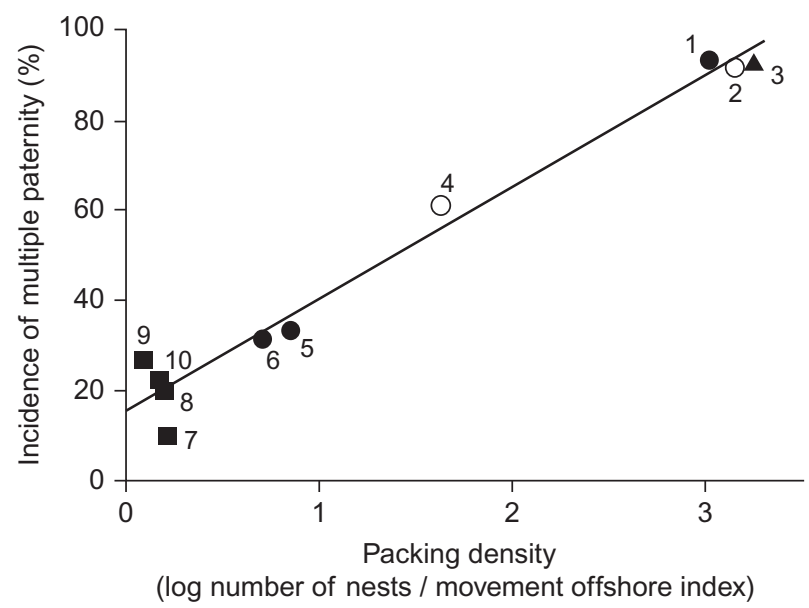

Fig. 4 The incidence of multiple paternity scales tightly with the packing density, where packing density was determined as the log of the number of nests divided by the offshore movement index (see Table 1). Plot symbols indicate different species as identified in Fig. 2A. The three points at the highest packing density are jittered so that they do not lie on top of each other. $1=$ loggerhead turtles Zakynthos (Greece); $2=$ green turtles Tortuguero (Costa Rica); $3=$ olive ridley turtles Ostional (Costa Rica); $4=$ green turtles (Ascension Island); $5=$ loggerhead turtles Mon Repos (Australia); $6=$ loggerhead turtles, Melbourne Beach, Florida (USA); $7=$ leatherback turtles Playa Grande (Costa Rica); $8=$ leatherback turtles Matura (Trinidad); $9=$ leatherback turtles St. Croix (US Virgin Islands); $10=$ leatherback turtles Gandoca (Costa Rica).

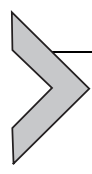

\section{MOVEMENT APPEARS CRITICAL TO ESTIMATING DENSITY AND MATE ENCOUNTER RATE}

Theoretical considerations have predicted that population density and sex ratios will often drive male-female encounter rate, although the implications for the resulting incidence of multiple paternity are not simple to predict and may depend on the relative costs vs benefits to females of multiple matings (Kokko and Mappes, 2013; Kokko and Rankin, 2006). Set against this backdrop, we might expect that where the extent of individual movements varies across populations, then population size alone may not provide a good approximation of density. Yet surprisingly this impact of animal movement does not appear to have been widely considered. Our findings provide strong evidence that the extent of individual movements in the breeding season varies widely across sea turtle rookeries and species, and has a profound impact on density and thereby male-female encounter rates and the incidence of multiple paternity. As such, we provide some 
of the strongest empirical evidence to date for the hypothesis that female sea turtles simply "give in" to unwanted mating attempts, termed "convenience polyandry" (Thornhill and Alcock, 1983).

Both the weak links between rookery size and the incidence of multiple paternity in sea turtles, as well as the broad differences in this incidence across species point to the profound role of their movement behaviour in driving male-female encounter rates. As a general rule, the instances of multiple paternity were high where nesting numbers were massive, such as for olive ridley turtles nesting at Ostional National Wildlife Refuge (Costa Rica) and green turtles nesting at Tortuguero (Costa Rica), where there are many tens of thousands of breeding individuals. At these sites, the high numbers of individuals alone likely ensure high rates of male female encounters. However, in contrast, the incidence of multiple paternity was very variable where nesting numbers were smaller, consistent with variable extents of individual movement at these rookeries. This variable extent of movement certainly seems to apply both across and within species. For example, generally leatherback turtles range broadly during the breeding season, with typical distances moved offshore of several $10 \mathrm{~s}$ of $\mathrm{km}$ (Eckert, 2002, 2006; Shillinger et al., 2010), most likely because this species often forages in deep water far from land. The broad dispersion of breeding leatherback turtles appears linked to the generally very low incidence of multiple paternity in this species, since even when nesting numbers are high the likely density, and hence male-female encounter rates, will be low. In contrast, green turtles tend to both feed and rest in shallow water, and hence their movements in the breeding season will generally be far less than in leatherbacks. For example, at Ascension Island (South Atlantic), satellite tracking has shown that individuals typically move only a few $\mathrm{km}$ offshore from their nesting beaches (Hays et al., 1999), a finding that is corroborated by records of depth utilisation that show individuals rest on the seabed in shallow water which is only found close to land at this site (Hays et al., 2004). In addition to the broad difference between species in the extent of their movements in the breeding season, even across rookeries of the same species, the extent of movement may vary. For loggerhead turtles in Greece, we showed very localised movements as have been reported previously at this site (Schofield et al., 2010), yet elsewhere, for example, in Florida, this species ranges more widely during the breeding season (Arendt et al., 2012).

Our key conclusion, that the incidence of multiple paternity scales with the density of turtles, could clearly be improved by further tracking studies 
both across other rookeries but also by having comparable raw tracking data sets collected with the same accuracy so that the same movement metrics could be applied easily across studies (Urbano et al., 2010). So we acknowledge that it is not ideal to develop a movement metric from disparate studies, and we encourage initiatives for data-sharing and archiving of data that are now becoming widespread both in the animal tracking community (e.g. Dwyer et al., 2015; Hunter et al., 2013; Kranstauber et al., 2011) and more broadly (Soranno et al., 2015). Furthermore, given the strong links we identified between packing density and the incidence of multiple paternity, for sites where there is no tracking data for breeding individuals we predict that for relatively large rookeries with a low incidence of multiple paternity, the breeding individuals likely range relatively more (e.g. green turtles at Heron Island, Australia) and vice versa. Given the wide availability of techniques for tracking marine species including sea turtles (Hays et al., 2016), testing these predictions for the extent of movement, should be a rewarding avenue to pursue.

Our findings suggest that females are not actively seeking to mate with multiple males, which would be expected if there were fitness benefits for females from promiscuous behaviour, but rather they simply give in to unwanted male mating. According to this hypothesis, females will generally resist mating more than once, unless the cost of resistance exceeds that of mating. Thus, females simply make the "best of a bad job" by opting for the less costly choice (Watson et al., 1998). Convenience polyandry has been demonstrated for some species of invertebrates (e.g. Cordero and Andrés, 2002; Rowe, 1992; Thiel and Hinojosa, 2003; Watson et al., 1998; Weigensberg and Fairbairn, 1994) and is the obvious hypothesis where there are little evident benefits of multiple mating to females, such as been found for some species of amphibians (Byrne and Roberts, 2004; Zhao et al., 2016), sharks (Griffiths et al., 2012; Nosal et al., 2013) and reptiles (Garner et al., 2002). Both multiple mating and resistance to mating are costly for females. However, if the costs of mating were high relative to costs of resistance, then there would be little or no multiple paternity occurring. Alternatively, should the costs of mating to females be sufficiently small, as appears to be the case in sea turtles, then where male encounter rates are high, submission to male coercion and hence higher levels of multiple paternity, are likely to occur. Certainly, there appear to be costs of resistance to mating in female turtles. For example, cameras attached to females have shown that they may need to swim fast and dive deeply to avoid mating which may incur high energetic costs (Reina et al., 2005). So when density 
is high, there may be little point in resisting male mating attempts, as another male will then soon arrive even if the current one is successfully rejected (Arnqvist, 1992; Rowe et al., 1994). Our evidence provides some of the strongest evidence to date that this scenario of not resisting male mating attempts occurs widely for sea turtles.

Our results extend on recent studies of other animals such as mammals and birds that are also starting to show that higher density can lead to increased female promiscuity (Ishibashi and Saitoh, 2008; Mayer and Pasinelli, 2013), with experimental work on insects further demonstrating that this can occur without females benefiting from multiple mating (Sandrin et al., 2015). Our findings also point to the value of being able to estimate encounter rates, for example, by directly tracking individuals. Certainly for a broad range of animals high-resolution tracking is possible, opening up the possibilities for these types of movement study across a broad spectrum of species (Hays et al., 2016), ideally improving on our approach here by tracking both males and female simultaneously. Furthermore, as well as improved tracking data sets, our approach of estimating packing density could be improved by estimating operational sex ratios, i.e., the relative number of breeding males and females. Generally, the number of breeding male turtles tends to be poorly known across sea turtle rookeries (Hays et al., 2010), but can potentially be assessed with targeted studies (e.g. Casale et al., 2014; Chaloupka and Limpus, 2001).

In summary, our work helps resolve a long-standing conundrum by supporting the suggestion (Alfaro-Núñez et al., 2015; Jensen et al., 2006; Lee and Hays, 2004; Wright et al., 2013) that multiple paternity generally offers no fitness benefits to female sea turtles and simply scales with the density of turtles on the breeding grounds. The use of movement data to estimate male-female encounter rates may allow the broader applicability of this conclusion to be assessed for other taxa.

\section{CONCLUSION}

We confirmed that the incidence of multiple paternity in sea turtles was only weakly linked to adult abundance at rookeries. For some species, such as the leatherback turtle, the incidence of multiple paternity was relatively low regardless of the size of the population, while for other species, such as the loggerhead turtle, the incidence of multiple paternity was highly variable, even for rookeries of similar size. 
1. If females benefit from mating many times, then we suggest that females ought to actively seek out mates and consequently, the incidence of multiple paternity should be generally high regardless of rookery size. Instead, our review found that the incidence of multiple paternity in sea turtles varied greatly among species and rookeries, and could be relatively low even for rookeries of moderate size. Therefore, for sea turtles, we suggest there is no indication that females are benefiting from promiscuous behaviour. Instead, it is more likely that females are acquiescing to extraneous matings to avoid the high costs incurred by attempting to reject the unwanted mates.

2. Our detailed tracking information on individuals supported our hypothesis that individual movement could determine the local packing density and potentially, the rate of encounter among breeding individuals within that particular locality.

3. Having incorporated movement data with rookery size data to obtain an estimate of packing density, we found a tight relationship between packing density and the incidence of multiple paternity. We predict that for relatively large rookeries with a low incidence of multiple paternity, breeding individuals are possibly ranging relatively more and vice versa. Testing these predictions should be a rewarding aim for future studies.

4. Advances in techniques in high-resolution tracking and remote monitoring of individuals should open up the possibilities for movement study in the context of understanding mating strategies across a broad spectrum of species, and improve on our approach here by tracking both males and female simultaneously, and estimating mate encounter rate more directly.

\section{ACKNOWLEDGEMENT}

We are grateful to Kostas Papafitsoros for the photograph.

\section{AUTHORS' CONTRIBUTIONS}

P.L.M.L. and G.C.H. conceived the study, analysed the data, prepared the figures and led the writing with contributions from all authors. P.L.M.L., G.S., R.I.H. and A.D.M. assembled the data.

\section{COMPETING INTERESTS}

The authors declare no competing interests.

\section{FUNDING}

P.L.M.L. and G.S. were supported by Deakin University funded postdoctoral positions. 


\section{REFERENCES}

Adams, E.M., Jones, A.G., Arnold, S.J., 2005. Multiple paternity in a natural population of a salamander with long-term sperm storage. Mol. Ecol. 14, 1803-1810.

Alfaro-Núñez, A., Jensen, M.P., Abreu-Grobois, F.A., 2015. Does polyandry really pay off? The effects of multiple mating and number of fathers on morphological traits and survival in clutches of nesting green turtles at Tortuguero. PeerJ 3. e880.

Allen, Z.C., Shah, N.J., Grant, A., Derand, G.-D., Bell, D., 2010. Hawksbill turtle monitoring in Cousin Island special reserve, Seychelles: an eight-fold increase in annual nesting numbers. Endang. Species Res. 11, 195-200.

Arendt, M.D., Segars, A.L., Byrd, J.I., Boynton, J., Whitaker, J.D., Parker, L., Owens, D.W., Blanvillain, G., Quattro, J.M., Roberts, M.A., 2012. Distributional patterns of adult male loggerhead sea turtles (Caretta caretta) in the vicinity of Cape Canaveral, Florida, USA during and after a major annual breeding aggregation. Mar. Biol. 159, 101-112.

Arnqvist, G., 1992. Pre-copulatory fighting in a water strider: inter-sexual conflict or mate assessment? Anim. Behav. 43, 559-567.

Arnqvist, G., Nilsson, T., 2000. The evolution of polyandry: multiple mating and female fitness in insects. Anim. Behav. 60, 145-164.

Avise, J.C., Liu, J.-X., 2011. Multiple mating and its relationship to brood size in pregnant fishes versus pregnant mammals and other viviparous vertebrates. Proc. Natl. Acad. Sci. U. S. A. 108, 7091-7095.

Bachan, A., 2009. The National Sea Turtle Tagging and Monitoring Program: A Report on the 2009 Nesting Season and the Launch of the Offshore Component. Turtle Village Trust, Trinidad and Tobago.

Baldwin, R., Hughes, G., Rince, R., 2003. Loggerhead turtles in the Indian Ocean. In: Bolten, A.B., Witherington, B.E. (Eds.), Loggerhead Sea Turtles. Smithsonian Books, Washington, DC, pp. 218-232.

Bollmer, J.L., Irwin, M.E., Rieder, J.P., Parker, P.G., 1999. Multiple paternity in loggerhead turtle clutches. Copeia 1999, 475-478.

Byrne, P.G., Roberts, J.D., 2004. Intrasexual selection and group spawning in quacking frogs (Crinia georgiana). Behav. Ecol. 15, 872-882.

Byrne, P.G., Roberts, J.D., 2012. Evolutionary causes and consequences of sequential polyandry in anuran amphibians. Biol. Rev. 87, 209-228.

Casale, P., Freggi, D., Maffucci, F., Hochscheid, S., 2014. Adult sex ratios of loggerhead sea turtles (Caretta caretta) in two Mediterranean foraging grounds. Sci. Mar. 78, 303-309.

Caspers, B.A., Krause, E.T., Hendrix, R., Kopp, M., Rupp, O., Rosentreter, K., Steinfartz, S., 2014. The more the better-polyandry and genetic similarity are positively linked to reproductive success in a natural population of terrestrial salamanders (Salamandra salamandra). Mol. Ecol. 23, 239-250.

Chaloupka, M., Limpus, C., 2001. Trends in the abundance of sea turtles resident in southern great barrier reef waters. Biol. Conserv. 102, 235-249.

Comision Nacional De Areas Naturales Protegidas, 2011. Programa de accion para la conservacion de la especie: Tortuga Caguama, Caretta caretta. Comision Nacional de Areas Naturales Protegidas, Mexico.

Conant, T., Somma, A., Lauritsen, A.M., Bibb, K., Possardt, E., 2014. Olive Ridley Sea Turtle (Lepidochelys olivacea): 5-Year Review and Summary. USFWS and NMSF, Maryland and Florida.

Connor, R.C., Heithaus, M.R., Barre, L.M., 2001. Complex social structure, alliance stability and mating access in a bottlenose dolphin 'super-alliance'. Proc. R. Soc. B Biol. Sci. 268, 263-267.

Cordero, A., Andrés, J.A., 2002. Male coercion and convenience polyandry in a calopterygid damselfly. J. Insect Sci. 2, 1-7. 
Crim, J.L., Spotila, L.D., Spotila, J.R., O'connor, M., Reina, R., Williams, C.J., Paladino, F.V., 2002. The leatherback turtle, Dermochelys coriacea, exhibits both polyandry and polygyny. Mol. Ecol. 11, 2097-2106.

Curtis, C., Williams, C., Spotila, J., 2000. Mating system of Caribbean leatherback turtles as indicated by analysis of microsatellite DNA from hatchlings and adult females. In: AbreuGrobois, F., Briseño-Dueñas, R., Márques, R., Sarti, L. (Eds.), Proceedings of the 18th Annual Symposium on Sea Turtle Biology and Conservation. NOAA Tech. Memo. US Department of Commerce-SEFC-436, Miami, FL, USA, p. 155.

Debade, X., Del Aquila, D.N., Harrison, E., 2009. Report on the 2008 Leatherback Program at Tortuguero, Costa Rica, p. 46. Costa Rica \& Florida.

Department of Environment and Heritage Protection, 2013. Green Turtle. Queensland Government, Queensland.

Dima, A.O.M., Solihin, D.D., Manalu, W., Boediono, A., 2015. Multiple paternity detection of olive ridley turtle, Lepidochelys olivacea populations by microsatellite marker as a genetic conservation strategy at Taman Buru Bena, Timor Island. IJSBAR 22, 403-413.

Duran, N., Dunbar, S.G., Escobar Iii, R.A., Standish, T.G., 2015. High frequency of multiple paternity in a solitary population of olive ridley sea turtles in Honduras. J. Exp. Mar. Biol. Ecol. 463, 63-71.

Dutton, P., Bixby, E., Davis, S., 2000. Tendency towards single paternity in leatherbacks detected with microsatellites. In: Abreu-Grobois, F., Briseño-Dueñas, R., Márques, R., Sarti, L. (Eds.), Proceedings of the 18th Annual Symposium on Sea Turtle Biology and Conservation. NOAA Tech. Memo. US Department of CommerceSEFC-436, Miami, FL, USA, p. 39.

Dwyer, R.G., Brooking, C., Brimblecombe, W., Campbell, H.A., Hunter, J., Watts, M., Franklin, C.E., 2015. An open Web-based system for the analysis and sharing of animal tracking data. Anim. Biotelem. 3, 1-11.

Eckert, S.A., 2002. Swim speed and movement patterns of gravid leatherback sea turtles (Dermochelys coriacea) at St. Croix, US Virgin Islands. J. Exp. Biol. 205, 3689-3697.

Eckert, S.A., 2006. High-use oceanic areas for Atlantic leatherback sea turtles (Dermochelys coriacea) as identified using satellite telemetered location and dive information. Mar. Biol. 149, 1257-1267.

Ekanayake, E.M.L., Kapurusinghe, T., Saman, M.M., Rathnakumara, D.S., Samaraweera, P., Ranawana, K.B., Rajakaruna, R.S., 2013. Paternity of green turtle (Chelonia mydas) clutches laid at Kosgoda, Sri Lanka. Herpetol. Conserv. Biol. 8, 27-36.

Ekanayake, E.M.L., Rajakama, R.S., Kapurusinghe, T., Saman, M.M., Rathnakumara, D.S., Samaraweera, P., Ranawana, K.B., 2010. Nesting behaviour of the green turtle at Kosgoda Rookery, Sri Lanka. Cey. J. Sci. (Bio. Sci.) 39, 109-120.

Figgener, C., Chacón-Chaverri, D., Jensen, M.P., Feldhaar, H., 2016. Paternity re-visited in a recovering population of Caribbean leatherback turtles (Dermochelys coriacea). J. Exp. Mar. Biol. Ecol. 475, 114-123.

Fitzsimmons, N.N., 1998. Single paternity of clutches and sperm storage in the promiscuous green turtle (Chelonia mydas). Mol. Ecol. 7, 575-584.

Florida Department of Environmental Protection, 2015. Sea Turtle Monitoring at Apalachicola National Estuarine Research Reserve. Department of Environmental Protection, Florida.

Frankel, A.M.D., 2009. Estimating Incidence of Multiple Paternity of Kemp's Ridley Sea Turtles on South Padre Island. Southwestern University, Texas.

Garcia-Gonzalez, F., Yasui, Y., Evans, J.P., 2015. Mating portfolios: bet-hedging, sexual selection and female multiple mating. Proc. R. Soc. B 282.

Garner, J.A., 2012. Reproductive Endocrinology of Nesting Leatherback Sea Turtles in St. Croix, U.S Virgin Islands. PhD thesis, Texas A\&M University, College Station, TX, USA. 
Garner, T.W.J., Gregory, P.T., Mccracken, G.F., Burghardt, G.M., Koop, B.F., Mclain, S.E., Nelson, R.J., 2002. Geographic variation of multiple paternity in the common garter snake (Thamnophis sirtalis). Copeia 2002, 15-23.

Georges, J.Y., Fossette, S., Billes, A., Ferraroli, S., Fretey, J., Gremillet, D., Le Maho, Y., Myers, A.E., Tanaka, H., Hays, G.C., 2007. Meta-analysis of movements in Atlantic leatherback turtles during the nesting season: conservation implications. Mar. Ecol. Prog. Ser. 338, 225-232.

González-Garza, B.I., Guzmán-Hernández, V., Cuevas Flores, E., 2012. Sea Turtle Conservation in the Yucatan Peninsula: An Update to Ongoing Initiatives. WIDECAST AGM, Telchac Puerto, Mexico.

González-Garza, B.I., Stow, A., Sánchez-Teyer, L.F., Zapata-Pérez, O., 2015. Genetic variation, multiple paternity, and measures of reproductive success in the critically endangered hawksbill turtle (Eretmochelys imbricata). Ecol. Evol. 5, 5758-5769.

Griffiths, A.M., Jacoby, D.M.P., Casane, D., Mchugh, M., Croft, D.P., Genner, M.J., Sims, D.W., 2012. First analysis of multiple paternity in an oviparous shark, the small-spotted catshark (Scyliorhinus canicula L.). J. Hered. 103, 166-173.

Harry, J.L., Briscoe, D.A., 1988. Multiple paternity in the loggerhead turtle (Caretta caretta). J. Hered. 79, 96-99.

Hattingh, K., Hajnoczky, N., Slade, B., 2014. Gnaraloo Bay and Gnaraloo Cape Farquhar Rookery, Summary Findings to End 2013/14. Gnaraloo Turtle Conservation Program, Western Australia.

Hays, G.C., Ferreira, L.C., Sequeira, A.M.M., Meekan, M.G., Duarte, C.M., Bailey, H., Bailleul, F., Bowen, W.D., Caley, M.J., Costa, D.P., Eguíluz, V.M., Fossette, S., Friedlaender, A.S., Gales, N., Gleiss, A.C., Gunn, J., Harcourt, R., Hazen, E.L., Heithaus, M.R., Heupel, M., Holland, K., Horning, M., Jonsen, I., Kooyman, G.L., Lowe, C.G., Madsen, P.T., Marsh, H., Phillips, R.A., Righton, D., Ropert-Coudert, Y., Sato, K., Shaffer, S.A., Simpfendorfer, C.A., Sims, D.W., Skomal, G., Takahashi, A., Trathan, P.N., Wikelski, M., Womble, J.N., Thums, M., 2016. Key questions in marine megafauna movement ecology. Trends Ecol. Evol. 31, 463-475.

Hays, G.C., Fossette, S., Katselidis, K.A., Schofield, G., Gravenor, M.B., 2010. Breeding periodicity for male sea turtles, operational sex ratios, and implications in the face of climate change. Conserv. Biol. 24, 1636-1643.

Hays, G.C., Luschi, P., Papi, F., Del Seppia, C., Marsh, R., 1999. Changes in behaviour during the inter-nesting period and post-nesting migration for Ascension Island green turtles. Mar. Ecol. Prog. Ser. 189, 263-273.

Hays, G.C., Metcalfe, J.D., Walne, A.W., Wilson, R.P., 2004. First records of flipper beat frequency during sea turtle diving. J. Exp. Mar. Biol. Ecol. 303, 243-260.

Hays, G.C., Schofield, G., Mazaris, A.D., 2014. Different male versus female breeding periodicity helps mitigate offspring sex ratio skews in sea turtles. Front. Mar. Sci. 1, 43.

Hirth, H.F., 1980. Some aspects of nesting behaviour and reproductive biology of sea turtles. Am. Zool. 20, 507-523.

Hoekert, W.E.J., Neufeglise, H., Schouten, A.D., Menken, S.B.J., 2002. Multiple paternity and female-biased mutation at a microsatellite locus in the olive ridley sea turtle (Lepidochelys olivacea). Heredity 89, 107-113.

Hunter, J., Brooking, C., Brimblecombe, W., Dwyer, R.G., Campbell, H.A., Watts, M.E., Franklin, C.E., 2013. In: OzTrack-e-Infrastructure to support the management, analysis and sharing of animal tracking data. 2013 IEEE 9th International Conference on E-Science (E-Science), pp. 140-147.

Ireland, J.S., Broderick, A.C., Glen, F., Godley, B.J., Hays, G.C., Lee, P.L.M., Skibinski, D.O.F., 2003. Multiple paternity assessed using microsatellite markers, in green turtles Chelonia mydas (Linnaeus, 1758) of Ascension Island, South Atlantic. J. Exp. Mar. Biol. Ecol. 291, 149-160. 
Ishibashi, Y., Saitoh, T., 2008. Effect of local density of males on the occurrence of multimale mating in gray-sided voles (Myodes rufocanus). J. Mammal. 89, 388-397.

Jennions, M.D., Petrie, M., 2000. Why do females mate multiply? A review of the genetic benefits. Biol. Rev. 75, 21-64.

Jensen, M.P., Abreu-Grobois, F.A., Frydenberg, J., Loeschcke, V., 2006. Microsatellites provide insight into contrasting mating patterns in arribada vs. non-arribada olive ridley sea turtle rookeries. Mol. Ecol. 15, 2567-2575.

Joseph, J., Shaw, P.W., 2011. Multiple paternity in egg clutches of hawksbill turtles (Eretmochelys imbricata). Conserv. Genet. 12, 601-605.

Kichler, K., Holder, M.T., Davis, S.K., Marquez, R., Owens, D.W., 1999. Detection of multiple paternity in the Kemp's ridley sea turtle with limited sampling. Mol. Ecol. 8, 819-830.

Kokko, H., Mappes, J., 2013. Multiple mating by females is a natural outcome of a null model of mate encounters. Entomol. Exp. Appl. 146, 26-37.

Kokko, H., Rankin, D.J., 2006. Lonely hearts or sex in the city? Density-dependent effects in mating systems. Philos. Trans. R Soc. Lond. B Biol. Sci. 361, 319-334.

Kranstauber, B., Cameron, A., Weinzerl, R., Fountain, T., Tilak, S., Wikelski, M., Kays, R., 2011. The Movebank data model for animal tracking. Environ. Model. Software $26,834-835$.

Lara-De La Cruz, L.I., Nakagawa, K.O., Cano-Camacho, H., Zavala-Paramo, M.G., Vazquez-Marrufo, G., Chassin-Noria, O., 2010. Detecting patterns of fertilization and frequency of multiple paternity in Chelonia mydas of Colola (Michoacan, Mexico). Hidrobiologica 20, 85-89.

Lasala, J.A., Harrison, J.S., Williams, K.L., Rostal, D.C., 2013. Strong male-biased operational sex ratio in a breeding population of loggerhead turtles (Caretta caretta) inferred by paternal genotype reconstruction analysis. Ecol. Evol. 3, 4736-4747.

Lee, P.L.M., 2008. Molecular ecology of marine turtles: new approaches and future directions. J. Exp. Mar. Biol. Ecol. 356, 25-42.

Lee, P.L.M., Hays, G.C., 2004. Polyandry in a marine turtle: females make the best of a bad job. Proc. Natl. Acad. Sci. U. S. A. 101, 6530-6535.

Limpus, C.J., 2009. A biological review of Australian marine turtles: 1. Loggerhead turtle Caretta caretta (Linnaeus). In: Fien, L. (Ed.), A Biological Review of Australian Marine Turtles. Qld Government, Environmental Protection Agency, Brisbane.

Limpus, C.J., Parmenter, C.J., Chaloupka, M., 2013. Monitoring of Coastal Sea Turtles: Gap Analysis 5. Flatback Turtles, Natator depressus, in the Port Curtis and Port Alma Region. Report Produced for the Ecosystem Research and Monitoring Program Advisory Panel as Part of Gladstone Ports Corporation's Ecosystem Research and Monitoring Program. Department of Environment and Heritage Protection, Queensland.

Long, C.A., 2013. Testing for Indirect Benefits of Polyandry in the Florida Green Turtle. MSc thesis, University of Central Florida, Orlando, FL, USA.

Madsen, T., 2008. Female nonavian reptiles benefit from multiple matings. Mol. Ecol. 17,3753 .

Margaritoulis, D., Rees, A.F., Dean, C.J., Riggall, T., 2011. Reproductive data of loggerhead turtles in Laganas Bay, Zakynthos Island, Greece, 2003-2009. Mar. Turt. Newsl. $131,2-6$.

Marine Research Unit Sabah Parks, 2007. Turtle Islands Park and Sipadan Island Turtle Research Report. Unpublished report as reported in SWOT.

Mast, R.B., Hutchinson, B.J., Villegas, P.E., 2014-2015. Sea turtles of Costa Rica. In: State of the World's Sea Turtles, vol. 10. p. 44. Washington DC.

Mayer, C., Pasinelli, G., 2013. New support for an old hypothesis: density affects extra-pair paternity. Ecol. Evol. 3, 694-705. 
Moore, M.K., Ball, R.M., 2002. Multiple paternity in loggerhead turtle (Caretta caretta) nests on Melbourne Beach, Florida: a microsatellite analysis. Mol. Ecol. 11, 281-288.

Mrosovsky, N., 1994. Sex ratios of sea turtles. J. Exp. Zool. 270, 16-27.

Mudsuk, N., Senanan, W., Monanunsap, S., Kaewsa, N., 2004. In: Detection of multiple paternity in green turtle clutches during a reproductive season at Khram Island, Thailand. In: Proceedings of the International Symposium on SEASTAR2000 and Bio-logging Science (The 5th SEASTAR2000 Workshop), pp. 1-5.

National Marine Fisheries Service, U.S.F.A.W.S, Semarnat, 2011. Bi-National Recovery Plan for the Kemp's Ridley Sea Turtle (Lepidochelys kempii). Second Revision, Silver Spring, Maryland.

Nielsen, J.T., 2010. Population Structure and the Mating System of Loggerhead Turtles (Caretta caretta). PhD thesis, University of Miami, Florida, USA.

Nosal, A.P., Lewallen, E.A., Burton, R.S., 2013. Multiple paternity in leopard shark (Triakis semifasciata) litters sampled from a predominantly female aggregation in la Jolla, California, USA. J. Exp. Mar. Biol. Ecol. 446, 110-114.

Nugent, S.P., 2012. Polyandry in the Leatherback Sea Turtle (Dermochelys coriacea). PhD thesis, University of Nevada, Reno, USA.

Olsson, M., Ujvari, B., Wapstra, E., Madsen, T., Shine, R., Bensch, S., 2005. Does mate guarding prevent rival mating in snow skinks? A test using AFLP. Herpetologica 61, 389-394.

Olsson, M., Wapstra, E., Schwartz, T., Madsen, T., Ujvari, B., Uller, T., 2011. In hot pursuit: fluctuating mating system and sexual selection in sand lizards. Evolution 65, 574-583.

Parker, P.G., Waite, T.A., Peare, T., 1996. Paternity studies in animal populations. In: Smith, T.B., Wayne, R.K. (Eds.), Molecular Genetic Approaches in Conservation. Oxford University Press, New York, pp. 413-423.

Peare, T., Parker, P.G., Irwin, M.E., 1998. Paternity analysis in the green sea turtle. In: Byles, R., Fernandez, Y. (Eds.), Proceedings of the 16th Annual Symposium on Sea Turtle Biology and Conservation. NOAA Technical Memorandum NMFSSEFSC-412, South Carolina, p. 116.

Pearse, D.E., Avise, J.C., 2001. Turtle mating systems: behavior, sperm storage, and genetic paternity. J. Hered. 92, 206-211.

Pfaller, J.B., Bjorndal, K.A., Chaloupka, M., Williams, K.L., Frick, M.G., Bolten, A.B., 2013. Accounting for imperfect detection is critical for inferring marine turtle nesting population trends. PLoS One 8. e62326.

Phillips, K.P., 2013. Molecular Ecology of Hawksbill Turtles Eretmochelys imbricata in the Seychelles. PhD thesis, University of East Anglia, Norwich, UK.

Phillips, K.P., Jorgensen, T.H., Jolliffe, K.G., Jolliffe, S.-M., Henwood, J., Richardson, D.S., 2013. Reconstructing paternal genotypes to infer patterns of sperm storage and sexual selection in the hawksbill turtle. Mol. Ecol. 22, 2301-2312.

Phillips, K.P., Mortimer, J.A., Jolliffe, K.G., Jorgensen, T.H., Richardson, D.S., 2014. Molecular techniques reveal cryptic life history and demographic processes of a critically endangered marine turtle. J. Exp. Mar. Biol. Ecol. 455, 29-37.

Prieto, C.G., Harrison, E., 2012. Report on the 2011 Green Turtle Program at Tortuguero, Costa Rica. Sea Turtle Conservancy and the Ministry of Environment, Energy and Telecommunications of Costa Rica, Costa Rica.

Purnama, D., Zamani, N.P., Farajallah, A., 2013. Microsatellite DNA analysis on the polyandry of Green Sea turtle Cheloniamydas. HAYATI J. Biosci. 20, 182-186.

Reichard, M., Le Comber, S.C., Smith, C., 2007. Sneaking from a female perspective. Anim. Behav. 74, 679-688.

Reina, R.D., Abernathy, K.J., Marshall, G.J., Spotila, J.R., 2005. Respiratory frequency, dive behaviour and social interactions of leatherback turtles, Dermochelys coriacea during the inter-nesting interval. J. Exp. Mar. Biol. Ecol. 316, 1-16. 
Rieder, J.P., Parker, P.G., Spontila, J.R., Irwin, M.E., 1998. The mating system of the leatherback turtle: a molecular approach. In: Byles, R., Fernandez, Y. (Eds.), Proceedings of the 16th Symposium on Sea Turtle Biology and Conservation. NOAA Tech. Memo. US Department of Commerce-SEFC-241, Miami, FL, USA, p. 120.

Rivas, M.L., Fernández, C., Marco, A., 2015. Nesting ecology and population trend of leatherback turtles Dermochelys coriacea at Pacuare nature reserve, Costa Rica. Oryx 1, 1-9.

Rowe, L., 1992. Convenience polyandry in a water strider: foraging conflicts and female control of copulation frequency and guarding duration. Anim. Behav. 44 (Pt. 2), 189-202.

Rowe, L., Arnqvist, G., Sih, A., Krupa, J.J., 1994. Sexual conflict and the evolutionary ecology of mating patterns: water striders as a model system. Trends Ecol. Evol. 9, 289-293.

Sandrin, L., Meunier, J., Raveh, S., Walser, J.C., Kolliker, M., 2015. Multiple paternity and mating group size in the European earwig, Forficula auricularia. Ecol. Entomol. 40, 159-166.

Scarborough, D.M., 2013. Comments in Response to Proposed Rule to Designate Specific Areas in the Terrestrial Environment as Critical Habitat for the Northwest Atlantic Ocean Distinct Population Segment of the Loggerhead Sea Turtle (Caretta caretta) Under the Endangered Species Act of 1973-78 FR 18000 (March 25,2013), 78 FR 42921 (July 18, 2013). Outer Banks Preservation Association, Buxton, N.C.

Schofield, G., Bishop, C.M., MacLean, G., Brown, P., Baker, M., Katselidis, K.A., Dimopoulos, P., Pantis, J.D., Hays, G.C., 2007. Novel GPS tracking of sea turtles as a tool for conservation management. J. Exp. Mar. Biol. Ecol. 347, 58-68.

Schofield, G., Lilley, M.K.S., Bishop, C.M., Brown, P., Katselidis, K.A., Dimopoulos, P., Pantis, J.D., Hays, G.C., 2010. Conservation hotspots: implications of intense spatial area use by breeding male and female loggerheads at the Mediterranean's largest rookery. Endang. Species Res. 10, 191-202.

Schofield, G., Scott, R., Dimadi, A., Fossette, S., Katselidis, K.A., Koutsoubas, D., Lilley, M.K.S., Pantis, J.D., Karagouni, A.D., Hays, G.C., 2013. Evidence-based marine protected area planning for a highly mobile endangered marine vertebrate. Biol. Conserv. 161, 101-109.

Shillinger, G.L., Swithenbank, A.M., Bograd, S.J., Bailey, H., Castelton, M.R., Wallace, B.P., Spotila, J.R., Paladino, F.V., Piedra, R., Block, B.A., 2010. Identification of high-use internesting habitats for eastern Pacific leatherback turtles: role of the environment and implications for conservation. Endang. Species Res. 10, 215-232.

Simmons, L.W., 2005. The evolution of polyandry: sperm competition, sperm selection, and offspring viability. Annu. Rev. Ecol. Evol. Syst. 36, 125-146.

Slatyer, R.A., Jennions, M.D., Backwell, P.R.Y., 2012a. Polyandry occurs because females initially trade sex for protection. Anim. Behav. 83, 1203-1206.

Slatyer, R.A., Mautz, B.S., Backwell, P.R., Jennions, M.D., 2012b. Estimating genetic benefits of polyandry from experimental studies: a meta-analysis. Biol. Rev. 87, 1-33.

Soranno, P.A., Cheruvelil, K.S., Elliott, K.C., Montgomery, G.M., 2015. It's good to share: why environmental scientists' ethics are out of date. Bioscience 65, 69-73.

Stewart, K.R., Dutton, P.H., 2011. Paternal genotype reconstruction reveals multiple paternity and sex ratios in a breeding population of leatherback turtles (Dermochelys coriacea). Conserv. Genet. 12, 1101-1113.

Stewart, K.R., Dutton, P.H., 2014. Breeding sex ratios in adult leatherback turtles (Dermochelys coriacea) may compensate for female-biased hatchling sex ratios. PLoS One 9. e88138.

Stokes, K.L., Fuller, W.J., Glen, F., Godley, B.J., Hodgson, D.J., Rhodes, K.A., Snape, R.T.E., Broderick, A.C., 2014. Detecting green shoots of recovery: the importance of long-term individual-based monitoring of marine turtles. Anim. Conserv. 17, 593-602. 
Taylor, M.L., Price, T.A.R., Wedell, N., 2014. Polyandry in nature: a global analysis. Trends Ecol. Evol. 29, 376-383.

Tedeschi, J.N., Mitchell, N.J., Berry, O., Whiting, S., Meekan, M., Kennington, W.J., 2015. Reconstructed paternal genotypes reveal variable rates of multiple paternity at three rookeries of loggerhead sea turtles (Caretta caretta) in Western Australia. Aust. J. Zool. 62, 454-462.

Theissinger, K., Fitzsimmons, N.N., Limpus, C.J., Parmenter, C.J., Phillott, A.D., 2009. Mating system, multiple paternity and effective population size in the endemic flatback turtle (Natator depressus) in Australia. Conserv. Genet. 10, 329-346.

Thiel, M., Hinojosa, I.A., 2003. Mating behavior of female rock shrimp Rhynchocinetes typus (Decapoda:Caridea) - indication for convenience polyandry and cryptic female choice. Behav. Ecol. Sociobiol. 55, 113-121.

Thornhill, R., Alcock, J., 1983. The Evolution of Insect Mating Systems. Harvard University Press, Cambridge, MA.

Tomillo, P.S., Velez, E., Reina, R.D., Piedra, R., Paladinos, F.V., Spotila, J.R., 2007. Reassessment of the leatherback turtle (Dermochelys coriacea) nesting population at Parque Nacional Marino Las Baulas, Costa Rica: effects of conservation efforts. Chelonian. Conserv. Biol. 6, 54-62.

Tregenza, T., Wedell, N., 2000. Genetic compatibility, mate choice and patterns of parentage: invited review. Mol. Ecol. 9, 1013-1027.

Tremblay, Y., Shaffer, S.A., Fowler, S.L., Kuhn, C.E., Mcdonald, B.I., Weise, M.J., Bost, C.A., Weimerskirch, H., Crocker, D.E., Goebel, M.E., Costa, D.R., 2006. Interpolation of animal tracking data in a fluid environment. J. Exp. Biol. 209, 128-140.

Troëng, S., Chacón, D., Dick, B., 2004. Possible decline in leatherback turtle Dermochelys coriacea nesting along the coast of Caribbean Central America. Oryx 38, 395-403.

Tucker, A.D., Fitzsimmons, N.N., Limpus, C.J., 1996. Conservation implications of internesting habitat use by Loggerhead turtles Caretta caretta in Woongarra Marine Park, Queensland, Australia. Pac. Conserv. Biol. 2, 157-166.

Turtle Expert Working Group, 2000. Assessment Update for the Kemp's Ridley and Loggerhead Sea Turtle Populations in the Western North Atlantic. U.S. Dep. Commer. NOAA Tech. Mem. NMFS-SEFSC-444, Miami, FL, USA, p. 115.

Uller, T., Olsson, M., 2005. Multiple copulations in natural populations of lizards: evidence for the fertility assurance hypothesis. Behaviour 142, 45-56.

Uller, T., Olsson, M., 2008. Multiple paternity in reptiles: patterns and processes. Mol. Ecol. 17, 2566-2580.

Urbano, F., Cagnacci, F., Calenge, C., Dettki, H., Cameron, A., Neteler, M., 2010. Wildlife tracking data management: a new vision. Philos. Trans. R. Soc. Lond., B, Biol. Sci. $365,2177-2185$.

US Fish and Wildlife Service, 2015. Archie Carr National Wildlife Refuge-Sea Turtle Nesting. Department of the Interior, Florida, USA.

Watson, P.J., Arnqvist, G., Stallmann, R.R., 1998. Sexual conflict and the energetic costs of mating and mate choice in water striders. Am. Nat. 151, 46-58.

Weber, S.B., Weber, N., Ellick, J., Avery, A., Frauenstein, R., Godley, B.J., Sim, J., Williams, N., Broderick, A.C., 2014. Recovery of the South Atlantic's largest green turtle nesting population. Biodivers. Conserv. 23, 3005-3018.

Weigensberg, I., Fairbairn, D.J., 1994. Conflicts of interest between the sexes: a study of mating interactions in a semiaquatic bug. Anim. Behav. 48, 893-901.

While, G.M., Uller, T., Bordogna, G., Wapstra, E., 2014. Promiscuity resolves constraints on social mate choice imposed by population viscosity. Mol. Ecol. 23, 721-732.

Widecast, 2008. Programa de Conservación de las Tortugas Marinas en Playa Gandoca. Costa Rica. 
Wright, L.I., Fuller, W.J., Godley, B.J., Mcgowan, A., Tregenza, T., Broderick, A.C., 2013. No benefits of polyandry to female green turtles. Behav. Ecol. 24, 1022-1029.

Yasui, Y., Garcia-Gonzalez, F., 2016. Bet-hedging as a mechanism for the evolution of polyandry, revisited. Evolution 70, 385-397.

Zbinden, J.A., Largiadèr, C.R., Leippert, F., Margaritoulis, D., Arlettaz, R., 2007. High frequency of multiple paternity in the largest rookery of Mediterranean loggerhead sea turtles. Mol. Ecol. 16, 3703-3711.

Zeh, J.A., Zeh, D.W., 2001. Reproductive mode and the genetic benefits of polyandry. Anim. Behav. 61, 1051-1063.

Zeh, J.A., Zeh, D.W., 2008. Maternal inheritance, epigenetics and the evolution of polyandry. Genetica 134, 45-54.

Zhao, M., Li, C., Zhang, W., Wang, H., Luo, Z., Gu, Q., Gu, Z., Liao, C., Wu, H., 2016. Male pursuit of higher reproductive success drives female polyandry in the Omei treefrog. Anim. Behav. 111, 101-110.

Zurita, F.V., Martinez, S.G.K., Carreno, S.R., Lopez, R.C., 2008. Nesting density of olive ridleys from Escobilla, Oaxaca does not correlate with the high frequency of multiple paternity. In: Dean, K., Castro, M.C.L. (Eds.), Proceedings of the 28th Annual Symposium on Sea Turtle Biology and Conservation. NOAA Technical Memorandum NMFS-SEFSC-602, Mexico, p. 157. 